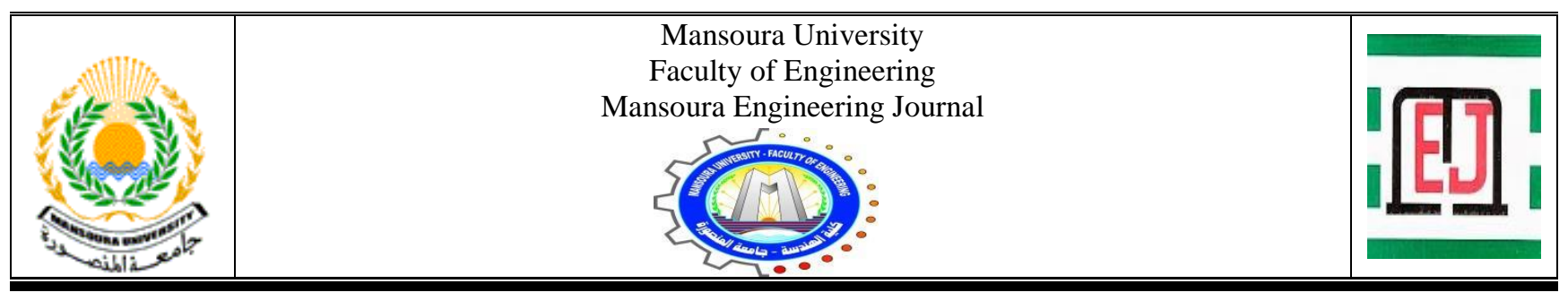

\title{
Flexural Capacity Formulae of Steel Cold-Formed I-Beam with Strengthened Hollow Tubular Flanges
}

\author{
Ashraf M. Abou-Rayan, Nader N. Khalil and Ayman A. Zaky*
}

\begin{tabular}{|l|}
\hline KEYWORDS: \\
Cold-formed, Finite \\
element, Tubular \\
flanges, Plate girder, \\
Strengthening. \\
\end{tabular}

Abstract- This research presents a new approach formula that predicts the
flexural behavior of steel cold-formed I-beam with strengthened hollow tubular
flanges. Rectangularity aspect ratio and strength of the strengthening material
effect on the flexural behavior of steel cold-formed I-beam with strengthened
hollow tubular flanges were studied and analyzed. A wide range of investigations
was carried to figure out the effect of the hollow flanges rectangularity aspect
ratio and its strengthening material. Eighty-eight numerical models were created
and analyzed using the finite element technique. Three-dimensional nonlinear
finite element models were prepared using eight nodes solid element with three
degrees of freedom per node. Material nonlinearity and geometric effects have
been considered in the model analysis. A good agreement between the
experimental work done by the authors [1] and FE-model results was achieved
and presented. The ultimate load values of the strengthened models were
presented and compared with non-strengthened models. The increase of
rectangularity aspect ratio and strength of the strengthening material lead to an
increase in the section capacity of the studied models. Finally, new equations for
the values of the section capacity of the strengthened sections were deduced,
taking into account the factors described in this study.

\section{INTRODUCTION}

$\mathrm{C}$ old-formed steel sections are widely used over the last decades, which arise in the automotive, aeronautical, and secondary structure elements.

Received: (10 July, 2021) - Revised: (21 August, 2021) - Accepted: (24 August, 2021)

Ashraf M. Abou-Rayan, Professor of structural engineering, is with the Department of Civil Engineering, Benha Faculty of Engineering, Benha University, Egypt (e-mail: ashraf.aboryan@bhit.bu.edu.eg).

Nader N. Khalil, Associate Professor, is with the Department of Civil Engineering, Benha Faculty of Engineering, Benha University, Egypt (e-mail: nader.gerges@bhit.bu.edu.eg).

*Corresponding author: Ayman A. Zaky, Assistant lecturer, is with the Department of Civil Engineering, Benha Faculty of Engineering, Benha University, Egypt (e-mail: ayman.soliman@bhit.bu.edu.eg)
Recently, cold-formed steel sections have been used as main structural elements, tubular flanges girder, and built-up coldformed columns. The hollow tubular flanges girder has greatly improved torsional rigidity due to a hollow compression flange and a higher moment of inertia of this section than a conventional I-girder with the same cross-section steel area and with a flat flange. Many different section shapes of beams with hollow tubular steel flanges have been developed for buildings, such as screw-fastened, welded hollow flange channel sections, I-beams with screw-fastened and welded rectangular hollow flanges, as shown in Fig. 1. Many experimental and numerical studies have investigated the structural behavior of cold-formed steel sections. Yu and Schafer [2] developed a finite element (FE) models using ABAQUS [3] to extend the experimental study of two series of beams with cold-formed $\mathrm{C}$ and $\mathrm{Z}$ steel sections. These models studied the effect of yield stress variations and moment gradient on the failure loads of these sections. Another study was presented by Shifferaw and Schafer [4] to 
propose an equation of the inelastic bending capacity of steel cold-formed sections subject to many modes of buckling, also, nonlinear FE models were provided to investigate the relationship between sections' slenderness, strain capacity, and bending strength. A procedure using FE models was suggested by Ma et al. [5] to obtain an optimized shape of cold-formed $\mathrm{C}$-sections subjected to either bending or compression according to (EN1993-1-3) [6].

Blandzi E. M. et al. [7] studied a box flanges channel beam and concluded that the beam buckling resistance with continuously welded flange to web joint is more than the riveted joint one. R. Siahaan et al. [8] investigated numerically the moment capacities of rivet fastened rectangular hollow flanges channel beam (RHFCB). The results obtained from the FE models were compared with the standard equations, AS/NZS 4600, AS 4100, and AISI S100 [9-11], taken into account the rivets spacing. They concluded that, increasing the spacing of the rivets of RHFCBs will decrease the moment capacities. R. Siahaan et al. [12] recommended the optimum rivet spacing of RHFCBs.

Dong and Sause [13] created a FE model to study the effect of cross-section dimensions, moment distribution, transverse web stiffeners, geometric imperfections, and residual stresses, on the lateral-torsional buckling strength of hollow tubular flanges steel girder. The flexural capacity of this section was evaluated by formulas extracted from these analytic results. Karunakaran and Santhi [14] presented an experimental and analytical study using the FE software ANSYS [15] to investigate the behavior of cold-formed steel rectangular hollow flanges Z-beam. They concluded that the load capacity of the studied beam by the welded connection (spot weld between the flange and web) is about $7 \%$ more than the riveted connection. Tondini and Morbioli [16] investigated the flexural capacity of a fully lateral-restrained Igirder with rectangular steel hollow flanges. They observed that using slender sections lead to a sudden decrease in the flexural capacity at the ultimate bending moment. Also, they have developed FE models using ANSYS [15] to extend the available findings in a wide range through a parametric study.

Kim and Sause [17] investigated the lateral-torsional buckling strength of the concrete-filled compression flange of the tubular flange girder. Using FE-models of the studied section, a parametric study was conducted to study the influence of material strength and girder geometry on the lateral-torsional buckling strength. They concluded that the concrete-filled compression flange of the tubular flange girder has a larger strength of the lateral-torsional buckling than the bare steel one. Flange torsional rigidity and web flexural rigidity ratio was a critical parameter in estimating the lateral distortional buckling strength of the hollow flange sections, Anapayan and Mahendran [18]. Hassanein et al. [19] studied the flexural behavior of hollow tubular flanges girders numerically using a FE model program ABAQUS. The girders were modeled as simply supported beam subjected to uniform bending. The models' analysis results proved that, at elastic lateral-torsional buckling range, stiffness and load capacity are larger than that obtained from the equivalent I-girder with flat flanges. Hassanein and Silvestre [20] have studied the long span tubular flange girders $>15 \mathrm{~m}$. They concluded that, even if the hollow tubular flange girders can bear much higher critical loads than I-girders with flat flanges, they still are susceptible to lateral distortional buckling. For steel girders with hollow flange and corrugated web, their plate webs effectively prevent the reduction in lateral buckling resistance and the web distortion that occur in girders with flat webs, Trahair, and Papangelis [21]. Kyvelou [22] has carried out experimental and numerical results to study the behavior of the flooring system composed of cold-formed C-steel section as a purlin and wood-based particle boards. These results showed that the behavior of the $\mathrm{C}$-section was improved compared with the bare steel section, this is due to the composite action in this type of system. He et al. [23] presented a numerical investigation on the behavior of web crippling of steel tubular filled by mortar. They presented design formulas to predict web crippling section capacity of the studied section.

To investigate the flexural behavior of steel cold-formed Ibeam with strengthened hollow tubular flanges, nineteen experimental specimens were prepared and tested by AbouRayan et al. [1]. After considering many factors as lightweight, low cost, and high strength, six different materials were used as a filler for the tubular flanges of the studied section to increase its buckling resistance, (Sawdust with cement mortar- Particleboard Wood- Sawdust with epoxySawdust with polyester - lightweight concrete - polymermortar). Filling compression flange with/without shear studs, and filling compression and tension flange were investigated. The experimental results showed that strengthened of the hollow tubular compression flanges increased the section capacity up to $67.21 \%$. Also, it was observed that strengthened of tension flanges and use of shear studs had a slight effect on the ultimate load of the strengthened compression flange only. To predict equations calculated the section capacity of the strengthened hollow tubular flanges, a wide range of numerical investigation is required. Therefore, this research is concerned with the development of 3-D FE models, and verification of these models have been demonstrated with reference to the experiments of Abou-Rayan et al. [1]. The developed models were used to extend the parametric study. The rectangularity aspect ratio of the tubular flanges and compressive strength of the strengthening material are considered in the presented parametric study.

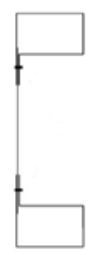

(a)

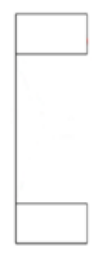

(b)

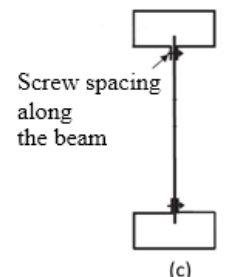

(c)

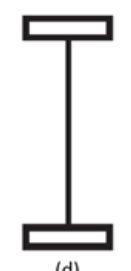

(d)
Fig. 1. Hollow flange channel and I-beam sections (a and c Screw fastened $-\mathrm{b}$ and $\mathrm{d}$ Welded)

\section{FINITE ELEMENT MODELING}

\subsection{General}

Eighty-eight three dimensions models were established to complete the parametric study. The general purpose finite element program ANSYS V 14.0 [15] was applied for 
nonlinear FE-analysis. The FE-models were loaded with two vertical loads and analyzed up to failure. Material and geometric nonlinearities have been taken into account in the FE models. Nineteen FE model results were verified with those obtained experimentally [1]. The verified FE model was used to establish the parametric study taking into account the rectangularity aspect ratio of the hollow tubular flanges and the compressive strength of the strengthening material. Failure modes and vertical displacements were recorded. Loads and vertical deflection at mid-span relationships have been analyzed and studied.

\subsection{Element types}

Steel I-beam section and all the strengthening materials except the lightweight concrete are modeled using 3-D solid element (solid185) having eight nodes with three translations ( $\mathrm{x}, \mathrm{y}$, and $\mathrm{z}$ directions) degrees of freedom per node. This element has plasticity, large deflection, and large strain capabilities. Also, a concrete solid element (solid65) was used to model the lightweight concrete. Self-drilling screws which use as shear connectors in the specimens were modeled using solid element (solid185) with $6.3 \mathrm{~mm}$ in diameter and $25 \mathrm{~mm}$ in length. The contact interaction between strengthening material and steel hollow tubular flange was considered in the developed model. Fig. 2 shows a 3-D model used in the analysis and investigations.

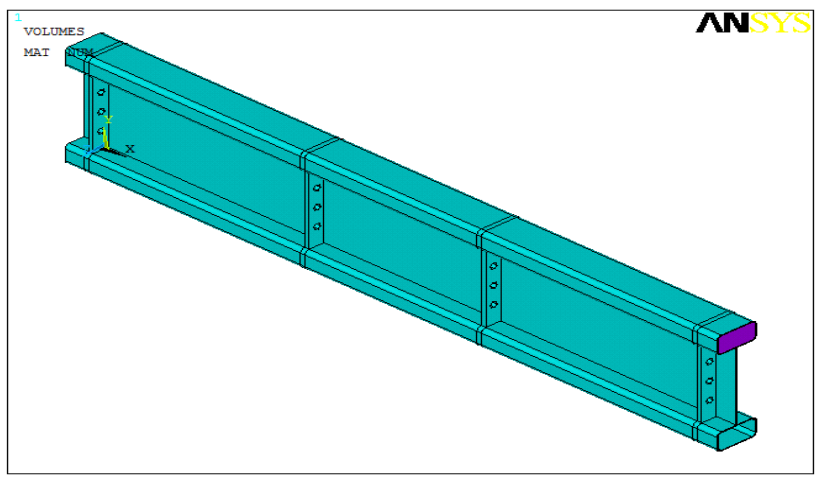

Fig. 2. FE-model of steel cold-formed I-beam with strengthened hollow tubular flanges.

\subsection{Material properties}

Steel material properties were modeled by non-linear and isotropic material using the bilinear stress-strain curve. The plastic modulus (the tangent modulus) of the bilinear stressstrain curve of steel was assumed to be equal to $0.5 \%$ of the elastic modulus $E_{s}$ as suggested by Bruneau et al. [24]. Shear studs and strengthening materials were modeled using linear elastic isotropic materials. The density and compressive strength of the strengthening materials which obtained experimentally were defined in Abou-Rayan et al. [1]. All properties of materials used in this study are summarized and presented in Table 1.

\subsection{Finite element mesh}

Free meshing was used all over the model with a maximum element size of a length of $20 \mathrm{~mm}$, as shown in Fig. 3. Refinement of meshing was applied at zones of high-stress concentration around the vertical stiffeners, i.e. zone of supports and point loads.

\subsection{Boundary conditions and loads.}

The dimensions of the cross-section of the modeled steel Ibeam have been considered along y and $\mathrm{z}$ directions, whereas the longitudinal dimension has been considered along the $\mathrm{x}$ direction. To simulate the lateral restraints of the specimen, two nodes at the top flange near the points load were constrained to displace in the z-direction. Also, to simulate the timber planks which used to prevent the shear failure of the web specimen, all nodes of the web plate between the point load and the support were constrained to be displaced in the zdirection. The load was applied by imposing increasing vertical displacement (in the y-direction) of the nodes around the holes of the web stiffeners which located at points load, while the translations of nodes around the holes of the web stiffeners which located at supports were prevented in the ydirection as in the experimental model. To perform a nonlinear static analysis, the load was applied using automatic load steps and sub-steps. The FE-model loading and its boundary conditions details are shown in Fig. 4.

TABLE 1

EXPERIMENTAL MATERIAL PROPERTIES [1]

\begin{tabular}{l||l||l||l||l}
\multicolumn{1}{c||}{ Material } & \multicolumn{1}{c||}{$\begin{array}{c}\text { Density } \\
\left(\mathbf{t} / \mathbf{m}^{\mathbf{3}}\right)\end{array}$} & $\begin{array}{c}\text { yield stress } \\
(\mathbf{M P a})\end{array}$ & $\begin{array}{c}\text { Modulus of elasticity } \\
(\mathbf{G P a})\end{array}$ & $\begin{array}{c}\text { Comp. Strength } \\
(\mathbf{M P a})\end{array}$ \\
\hline Steel I-beam $($ Tubular flanges) & - & 371 & 208.8 & - \\
\hline Steel I-beam $($ Web) & - & 367 & 208.8 & - \\
\hline Self-drilling screws & - & - & 210 & - \\
\hline Particle board wood & 0.745 & - & 2.3 & 14.07 \\
\hline Sawdust with cement mortar & 1.985 & - & 19.2 & 18.82 \\
\hline Sawdust with epoxy resin & 0.766 & - & 6.53 & 27.04 \\
\hline Light weight concrete & 2.00 & - & 24.4 & 30.38 \\
\hline Sawdust with polyester resin & 0.92 & - & 7.31 & 34.11 \\
\hline Polymer-mortar & 2.00 & - & 9 & 65.05
\end{tabular}




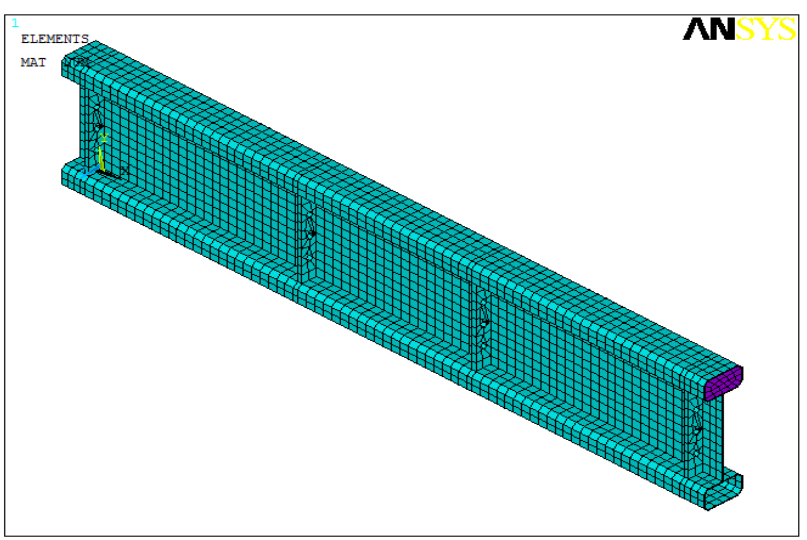

Fig. 3. Meshing of the FE-models

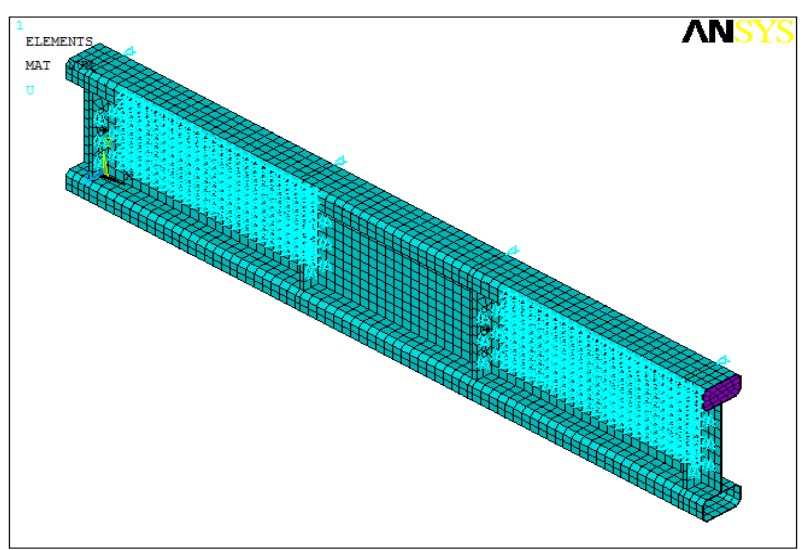

Fig. 4. FE-Models boundary conditions

\section{VERIFICATION OF FE-MODELS.}

\subsection{Modes of failure.}

The results of FE-models were compared with those obtained from the nineteen specimens' experimental results, Abou-Rayan et al. [1]. Failure modes, ultimate loads, and mid-span deflections at the ultimate load are the main results recorded and analyzed. Good agreement was observed between FE analysis and experimental modes of failure. Local buckling occurred at the mid-span for the control specimen, and at loading points for strengthened hollow flanges as shown in Fig. (5 a, b).

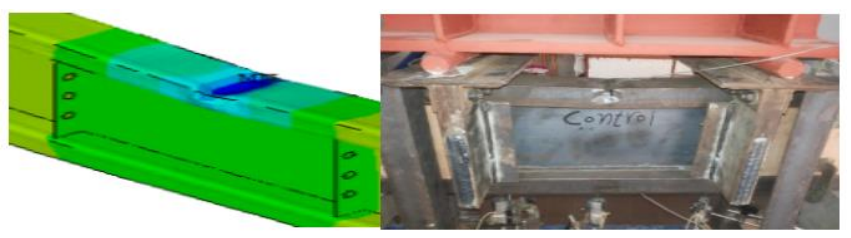

(a) Mode of failure of control specimens

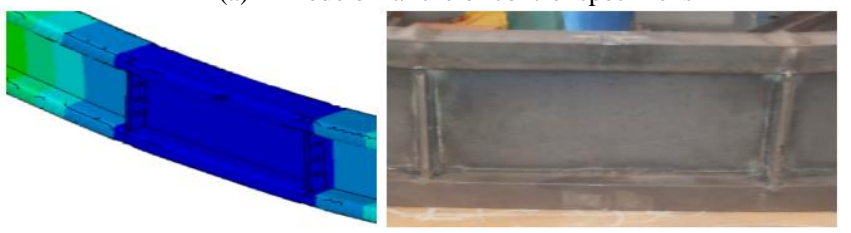

(b) Mode of failure of strengthened specimens

Fig. 5. Modes of failure of FE-Models and experimental tests.

\subsection{Ultimate loads and corresponding mid-span deflections.}

The mathematical mean difference and loads-deflections relationships were used to figure out the accuracy between results obtained experimentally and those obtained from FEmodels. The experimental and numerical results, ultimate loads, and mid-span deflections were recorded and presented in Table 2. Also, loads-deflections relationships of the experimental and numerical results were presented in Fig. (6 a-s). It can be noticed that, there is a very good agreement between the experimental and FE-models results where, as the mean difference was up to $4.52 \%$ and $15.84 \%$ for ultimate loads and mid-span deflections, respectively. Finally, the above mentioned results show the reliability of the FE-models and its validity to create the parametric study as an alternative analysis method instead of expensive experimental tests.

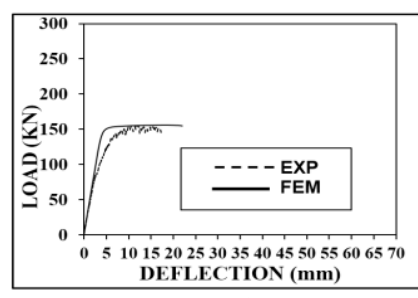

(a) Control.

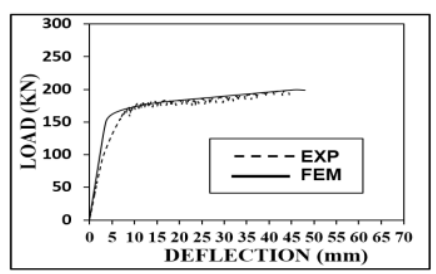

(c) B-PBW-U.

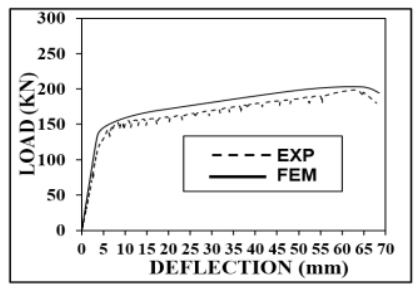

(e) A-SCM-U.

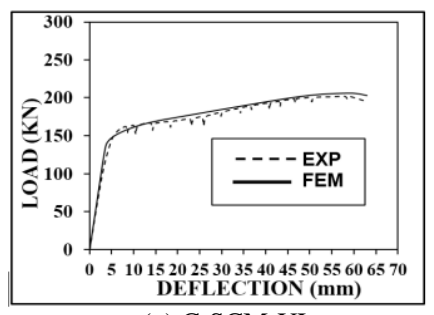

(g) C-SCM-UL.

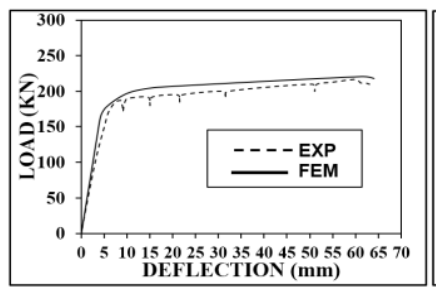

(i) B-SE-U,

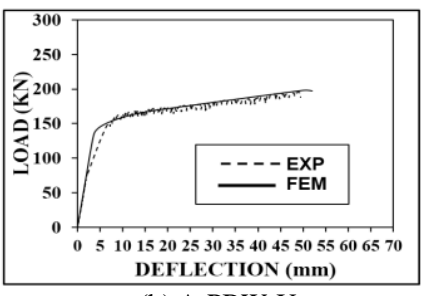

(b) A-PBW-U,

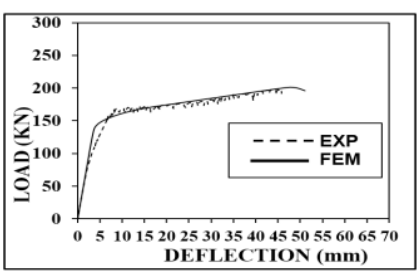

(d) C-PBW-UL.

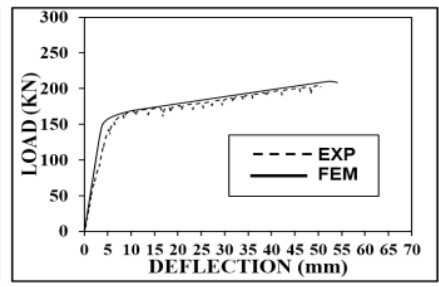

(f) B-SCM-U.

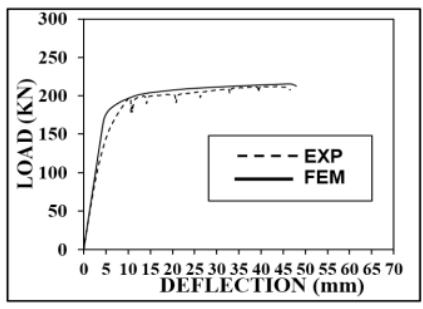

(h) A-SE-U.

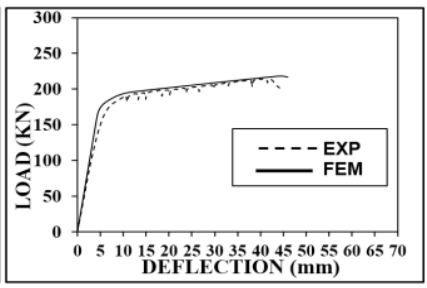

(j) C-SE-UL. 


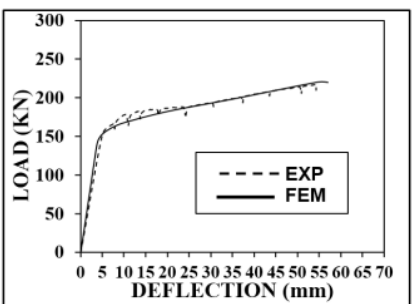

(k) A-LWC-U.

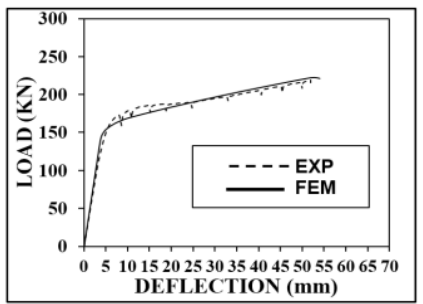

(m) C-LWC-UL.

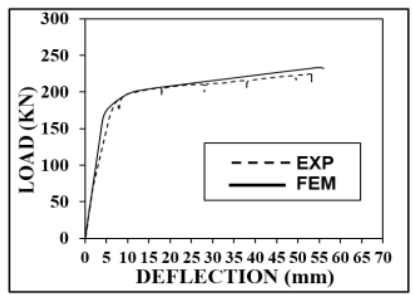

(o) B-SP-U.

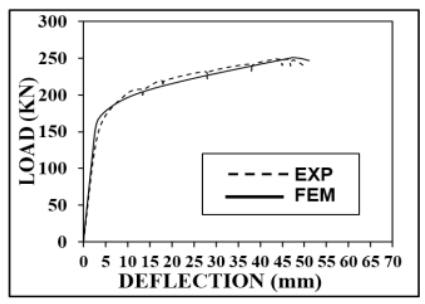

(q) A-PM-U.

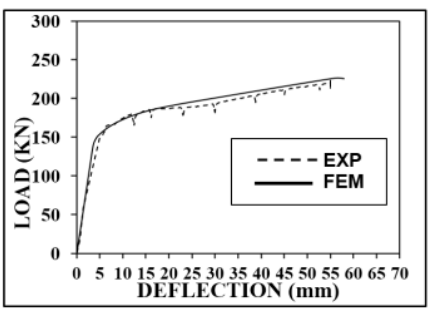

(l) B-LWC-U.

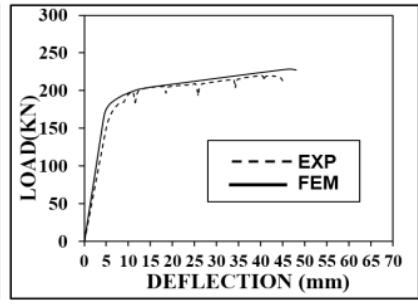

(n) A-SP-U.

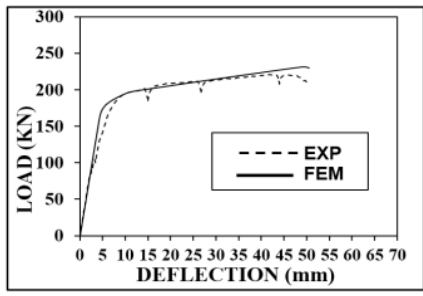

(p) C-SP-UL.

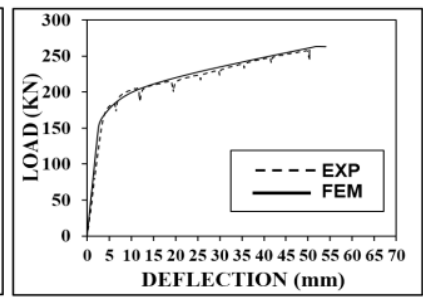

(r) B-PM-U.

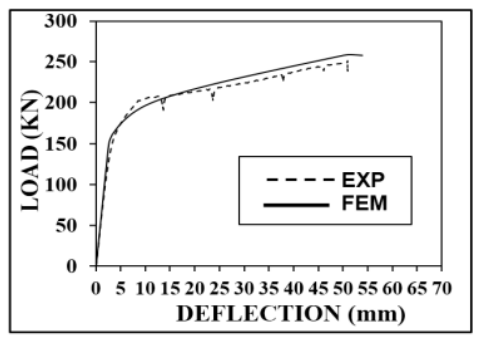

(s) C-PM-UL.

Fig. 6. Comparison of loads-deflections relationships of the experimental \& FE-model results.

\section{PARAMETRIC STUDY.}

An extended parametric study was carried out and listed in Table 3. The results were investigated to figure out the effect of rectangularity aspect ratio of the steel flanges $\left(b_{\mathrm{f}} / \mathrm{d}_{\mathrm{f}}\right)$ and the compressive strength of the strengthening material of the flanges $\left(f_{c}\right)$ on section flexural capacity of the studied steel section. The studied rectangularity aspect ratios $\left(\mathrm{b}_{\mathrm{f}} / \mathrm{d}_{\mathrm{f}}\right)$ are $0.5,1,1.5$, and 2 for steel and strengthened hollow tubular flange. Also, 200, 300, 400, 500, 600, 700, and 800 $\mathrm{kg} / \mathrm{cm}^{2}$ were the compressive strength used for the hollow flanges strengthening material $\left(\mathrm{f}_{\mathrm{c}}\right)$. The parametric study was classified into 4 series, steel flanges without strengthening, top flange strengthened with/without shear studs, and strengthened top and bottom flanges.

TABLE 2:

EXPERIMENTAL TESTS AND FE-MODELS RESULTS COMPARISONS.

\begin{tabular}{|c|c|c|c|c|c|c|c|}
\hline Specimen & $\begin{array}{l}\text { Strengthening } \\
\text { materials }\end{array}$ & $\begin{array}{c}\text { Exp. ultimate } \\
\text { loads }(\mathrm{kN})\end{array}$ & \begin{tabular}{|} 
FE-model \\
ultimate loads \\
$(\mathrm{kN})$
\end{tabular} & \begin{tabular}{|} 
Exp. mid-span \\
deflections \\
$(\mathbf{m m})$
\end{tabular} & \begin{tabular}{||c||} 
FE-model \\
mid-span \\
deflections $(\mathrm{mm})$
\end{tabular} & $\begin{array}{c}\text { Ultimate load } \\
\text { M.D. (\%). }\end{array}$ & \begin{tabular}{|c} 
Mid-span \\
deflection M.D. \\
$(\%)$.
\end{tabular} \\
\hline Control & - & 154.89 & 161.89 & 17.01 & 18.35 & +4.52 & +7.88 \\
\hline$A-P B W-U$ & \multirow{3}{*}{ Particle board wood } & 195.45 & 197.86 & 49.30 & 50.00 & +1.23 & +1.42 \\
\hline$B-P B W-U$ & & 198.77 & 203.54 & 44.00 & 45.50 & +2.40 & +3.41 \\
\hline$C-P B W-U L$ & & 198.46 & 201.00 & 46.44 & 47.00 & +1.28 & +1.21 \\
\hline$A-S C M-U$ & \multirow{3}{*}{$\begin{array}{l}\text { Sawdust with cement } \\
\text { mortar }\end{array}$} & 198.55 & 202.50 & 62.52 & 64.50 & +1.99 & +3.17 \\
\hline$B-S C M-U$ & & 204.05 & 209.50 & 49.03 & 52.00 & +2.67 & +6.06 \\
\hline$C-S C M-U L$ & & 202.07 & 206.10 & 54.00 & 59.00 & +1.99 & +9.26 \\
\hline$A-S E-U$ & \multirow{3}{*}{ Sawdust with epoxy } & 212.51 & 215.72 & 43.65 & 46.50 & +1.51 & +6.53 \\
\hline$B-S E-U$ & & 216.80 & 220.75 & 58.70 & 61.50 & +1.82 & +4.77 \\
\hline$C-S E-U L$ & & 214.52 & 218.33 & 42.00 & 44.00 & +1.78 & +4.76 \\
\hline$A-L W C-U$ & \multirow{3}{*}{$\begin{array}{l}\text { Light weight } \\
\text { concrete }\end{array}$} & 217.34 & 220.08 & 54.21 & 54.80 & +1.26 & +1.09 \\
\hline$B-L W C-U$ & & 223.66 & 226.71 & 55.00 & 56.00 & +1.36 & +1.82 \\
\hline$C-L W C-U L$ & & 219.17 & 221.95 & 50.18 & 52.00 & +1.27 & +3.63 \\
\hline
\end{tabular}


TABLE 2: continued

\begin{tabular}{|c|c|c|c|c|c|c|c|}
\hline Specimen & $\begin{array}{l}\text { Strengthening } \\
\text { materials }\end{array}$ & $\begin{array}{c}\text { Exp. ultimate } \\
\text { loads }(\mathrm{kN})\end{array}$ & \begin{tabular}{||c|} 
FE-model \\
ultimate loads \\
$(\mathrm{kN})$
\end{tabular} & \begin{tabular}{|c|}
$\begin{array}{c}\text { Exp. mid-span } \\
\text { deflections } \\
(\mathrm{mm})\end{array}$ \\
\end{tabular} & \begin{tabular}{||c|} 
FE-model \\
mid-span \\
deflections $(\mathrm{mm})$
\end{tabular} & $\begin{array}{l}\text { Ultimate load } \\
\text { M.D.(\%). }\end{array}$ & $\begin{array}{l}\text { Mid-span } \\
\text { deflection } \\
\text { M.D.(\%). }\end{array}$ \\
\hline$A-S P-U$ & \multirow{3}{*}{$\begin{array}{l}\text { Sawdust with } \\
\text { polyester }\end{array}$} & 219.94 & 228.12 & 42.50 & 46.00 & +3.72 & +8.24 \\
\hline$B-S P-U$ & & 225.41 & 233.00 & 53.22 & 54.50 & +3.37 & +2.41 \\
\hline$C-S P-U L$ & & 221.41 & 231.00 & 42.30 & 49.00 & +4.33 & +15.84 \\
\hline$A-P M-U$ & \multirow{3}{*}{ Polymer-mortar } & 249.52 & 256.05 & 47.10 & 47.32 & +2.62 & +0.47 \\
\hline$B-P M-U$ & & 259.00 & 263.41 & 50.02 & 51.78 & +1.70 & +3.52 \\
\hline$\overline{C-P M-U L}$ & & 251.54 & $\mid 258.93$ & 50.12 & 51.50 & +2.94 & $\mid+2.75$ \\
\hline
\end{tabular}

TABLE 3:

VARIABLES OF THE PARAMETRIC STUDY.

\begin{tabular}{|c|c|c|c|c|c|c|c|c|c|c|c|c|c|}
\hline \multirow[b]{2}{*}{$\begin{array}{c}\text { Model } \\
\text { No. }\end{array}$} & \multicolumn{7}{|c|}{ Steel dimensions (mm) } & \multicolumn{3}{|c|}{ Parameter study } & \multirow[b]{2}{*}{\begin{tabular}{||c} 
Top \\
flange
\end{tabular}} & \multirow[b]{2}{*}{\begin{tabular}{||l} 
Shear \\
studs
\end{tabular}} & \multirow[b]{2}{*}{$\begin{array}{l}\text { bottom } \\
\text { flange }\end{array}$} \\
\hline & $\mathbf{d}_{\mathrm{sec}}$ & $\mathbf{b}_{\mathrm{f}}$ & $d_{\mathrm{f}}$ & $\mathbf{t}_{\mathrm{f}}$ & $\mathbf{r}$ & $\mathbf{h}_{\mathbf{w}}$ & $\mathbf{t}_{\mathbf{w}}$ & \begin{tabular}{|c|} 
Rectangularity \\
aspect ratio of the \\
steel flanges $\left(b_{\mathrm{f}} / d_{\mathrm{f}}\right)$ \\
\end{tabular} & $\begin{array}{c}\text { Compressive strength of } \\
\text { strengthening material }\left(\mathbf{f}_{\mathrm{c}}\right) \\
\left(\mathrm{kg} / \mathrm{cm}^{2}\right)\end{array}$ & Model series & & & \\
\hline 1 & 400 & 50 & 100 & 2 & 8 & 200 & 2 & 0.5 & - & - & Null & Null & Null \\
\hline 2 & 350 & 75 & 75 & 2 & 8 & 200 & 2 & 1 & - & - & Null & Null & Null \\
\hline 3 & 320 & 90 & 60 & 2 & 8 & 200 & 2 & 1.5 & - & - & Null & Null & Null \\
\hline 4 & 300 & 100 & $\mid 50$ & 2 & 8 & 200 & $\mid 2$ & 2 & - & - & Null & Null & Null \\
\hline $5-11$ & 400 & 50 & 100 & 2 & 8 & 200 & 2 & 0.5 & $200,300,400,500,600,700,800$ & A & $\sqrt{ }$ & Null & Null \\
\hline $12-18$ & 350 & 75 & 75 & 2 & 8 & 200 & 2 & 1 & $200,300,400,500,600,700,800$ & $\mathrm{~A}$ & V & Null & Null \\
\hline $19-25$ & 320 & 90 & 60 & 2 & 8 & 200 & 2 & 1.5 & $200,300,400,500,600,700,800$ & $\mathrm{~A}$ & $\sqrt{ }$ & Null & Null \\
\hline $26-32$ & 300 & 100 & 50 & 2 & 8 & 200 & 2 & 2 & $200,300,400,500,600,700,800$ & A & $\sqrt{ }$ & Null & Null \\
\hline $33-39$ & 400 & 50 & 100 & 2 & 8 & 200 & 2 & 0.5 & $200,300,400,500,600,700,800$ & $\mathrm{~B}$ & $\sqrt{ }$ & $\sqrt{ }$ & Null \\
\hline $40-46$ & 350 & 75 & 75 & 2 & 8 & 200 & 2 & 1 & $200,300,400,500,600,700,800$ & $\mathrm{~B}$ & $\sqrt{ }$ & $\sqrt{ }$ & Null \\
\hline $47-53$ & 320 & 90 & 60 & 2 & 8 & 200 & 2 & 1.5 & $200,300,400,500,600,700,800$ & $\mathrm{~B}$ & $\sqrt{ }$ & $\sqrt{V}$ & Null \\
\hline $54-60$ & 300 & 100 & 50 & 2 & 8 & 200 & 2 & 2 & $200,300,400,500,600,700,800$ & $\mathrm{~B}$ & V & V & Null \\
\hline $61-67$ & 400 & 50 & 100 & 2 & 8 & 200 & 2 & 0.5 & $200,300,400,500,600,700,800$ & $\mathrm{C}$ & $\sqrt{2}$ & Null & $\sqrt{ }$ \\
\hline $68-74$ & 350 & 75 & 75 & 2 & 8 & 200 & 2 & 1 & $200,300,400,500,600,700,800$ & $\mathrm{C}$ & $\sqrt{ }$ & Null & $\sqrt{ }$ \\
\hline $75-81$ & 320 & 90 & 60 & 2 & 8 & 200 & 2 & 1.5 & $200,300,400,500,600,700,800$ & $\mathrm{C}$ & $\sqrt{ }$ & Null & $\sqrt{1}$ \\
\hline $82-88$ & 300 & 100 & 50 & 2 & 8 & 200 & 2 & 2 & $200,300,400,500,600,700,800$ & $\mathrm{C}$ & V & Null & $\| \sqrt{ }$ \\
\hline
\end{tabular}

4.1. Effect of the rectangularity aspect ratio of the tubular flanges.

Fig. (7 a, b, c) represent the relationships between section capacity gain due to strengthen the tubular flanges and its rectangularity aspect ratio for each compressive strength used. Section capacity gain was calculated as a percentage of the capacity of control model ((the ultimate load of the strengthened flanges model minus the ultimate load of the control model) divided by the ultimate load of the control model). To study the effect of strengthening the flanges on the flexural behavior of the studied steel section, three series A, B, and $\mathrm{C}$ were considered. Series A includes the models with strengthened the compression flanges without shear studs, series B uses the screw bolts as shear studs, finally, series C includes the models with strengthened its compression and tension flanges without shear studs.

For series A, it was observed that use the rectangularity aspect ratio for flanges equal to $0.5,1,1.5$, and 2 led to increase the section capacity compared to the control specimen by percentages ranged from $86.29 \%$ to $137.27 \%$, $72.64 \%$ to $128.78 \%, 48.81 \%$ to $92.51 \%$, and $32.55 \%$ to $66.21 \%$, respectively (for different compressive strength of the strengthening material). For series $\mathrm{B}$, the increased percentages ranged from $93.45 \%$ to $153.62 \%, 77.83 \%$ to $139.62 \%, 52.09 \%$ to $105.39 \%$, and $35.04 \%$ to $76.20 \%$, respectively. Also, it was found that the section capacity 
increased by percentages ranged from $3.84 \%$ to $7.56 \%, 3.01 \%$ to $5.27 \%, 2.20 \%$ to $6.69 \%$, and $1.88 \%$ to $6.01 \%$, respectively (for different compressive strength of the strengthening material) compared with similar models results obtained from series A. Finally, series $\mathrm{C}$ show an increasing percentages ranged from $91.43 \%$ to $141.82 \%, 76.96 \%$ to $132.65 \%, 51.81 \%$ to $94.84 \%$, and $34.85 \%$ to $67.72 \%$, respectively. Also, it was found that, the section capacity increased by percentages ranged from $1.92 \%$ to $3.43 \%, 1.66 \%$ to $3.20 \%, 1.19 \%$ to $2.68 \%$, and $0.91 \%$ to $2.37 \%$, respectively (for different compressive strength of the strengthening material) compared with similar models results obtained from series A.

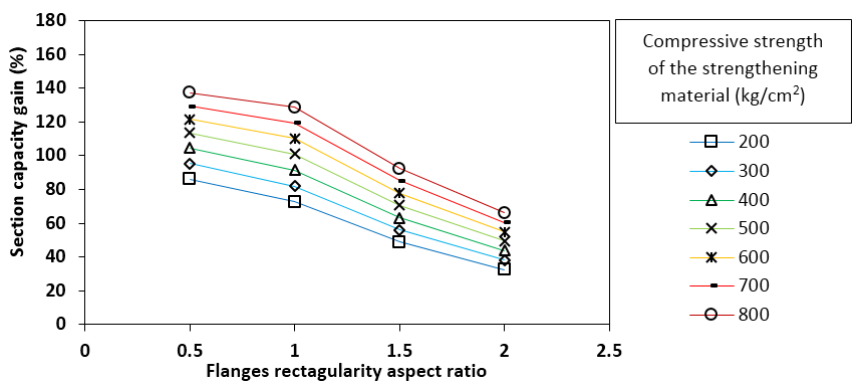

(a) Series A (strengthened of compression flange without shear studs).

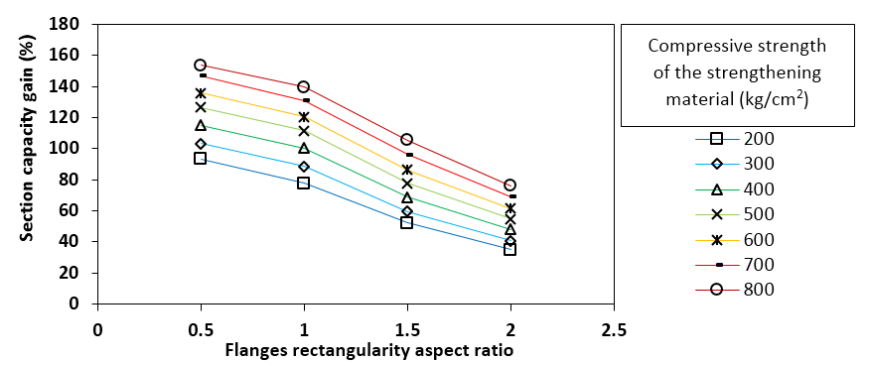

(b) Series B (strengthened of compression flange with shear studs).

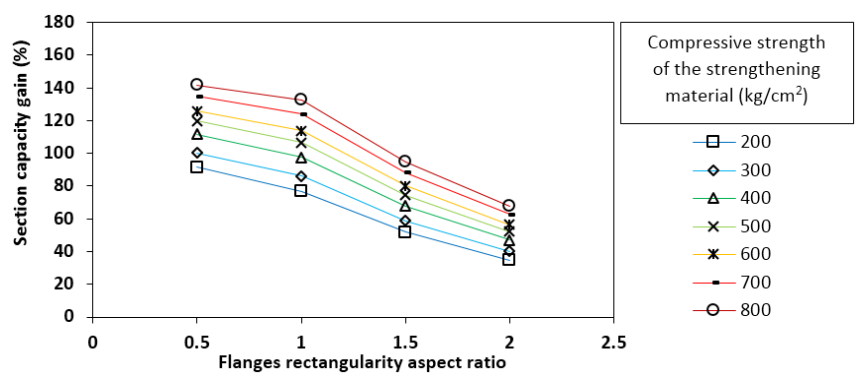

(c) Series C (strengthened of compression and tension flanges).

Fig. 7. Section capacity gain w.r.t tubular flanges rectangularity aspect ratio

\subsection{Effect of the compressive strength of the strengthening material.}

Fig. ( 8 a, b, c) represented the relationships between section capacity gain due to strengthening tubular flanges and the compressive strength values of its strengthening material for each aspect ratio used. Ultimate load results of the strengthened flanges models were compared with those obtained from the control models.

It was observed that, strengthening the compression flange only (i.e. Series A) by strengthening material with compressive strength ranged from 200 to $800 \mathrm{~kg} / \mathrm{cm}^{2}$, led to increase of the section capacity compared to the control steel specimen by percentages ranged from $32.55 \%$ to $137.27 \%$ for different rectangularity aspect ratio of the steel flanges. Also, it was observed that strengthening the compression flange with shear studs (i.e. Series B), led to increase in the section capacity compared to the control steel specimen by percentages ranged from $35.04 \%$ to $153.62 \%$ for different rectangularity aspect ratio of the steel flanges, while the increasing of the section capacity compared to the control steel specimen ranged from $34.85 \%$ to $141.82 \%$, (for specimens of series $\mathrm{C}$ ), indicating that stiffening the tension flange did not show a remarkable effect on the section capacity of the specimens.

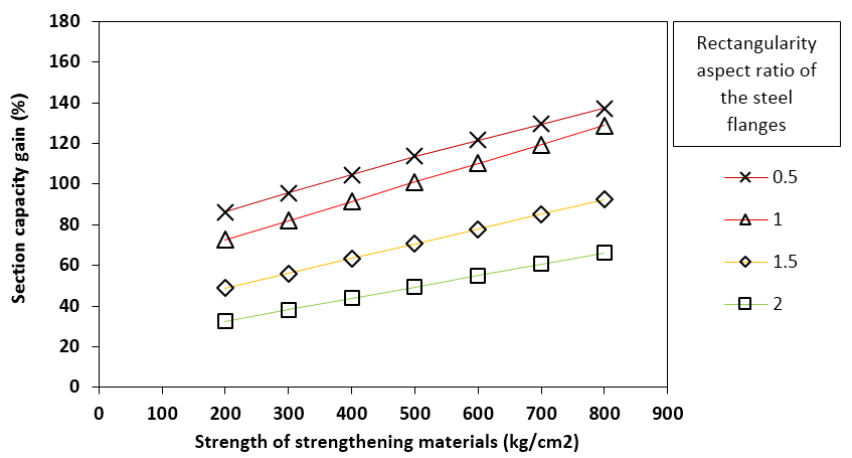

(a) Series A (strengthened of compression flange without shear studs).

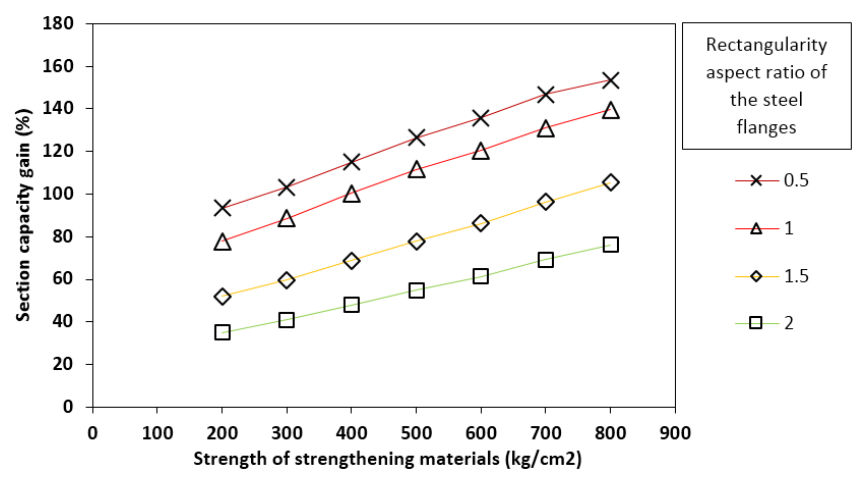

(b) Series B (strengthened of compression flange with shear studs).

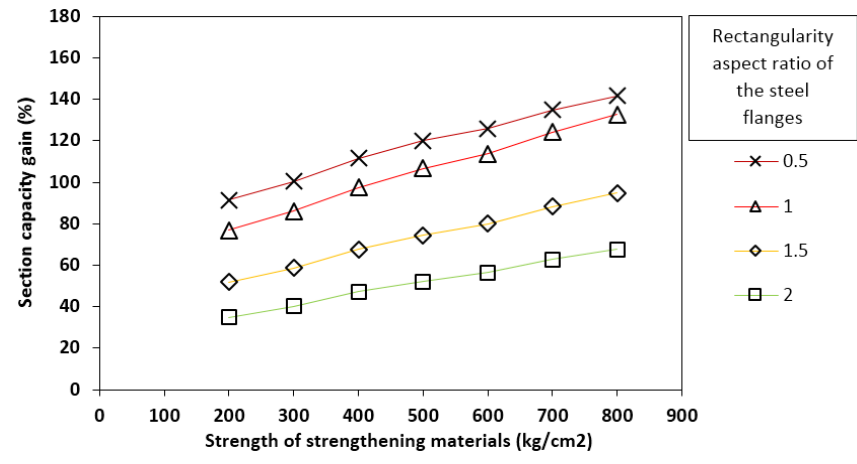

(b) Series $\mathrm{C}$ (strengthened of compression and tension flanges).

Fig. 8. Section capacity gain w.r.t strength values of the flanges strengthening materials. 


\section{New Approach Formula That Predicts The Flexural Capacity Of Steel Cold-Formed I-Beam With Strengthened Hollow Tubular Flanges.}

For predicting the flexure capacity gain of the steel coldformed I-beam with strengthened hollow tubular flanges (which calculated as a percentage of the control specimen capacity) at any value of the rectangularity aspect ratio of the steel flanges and the compressive strength of the used strengthening material, a new formulas in Tables 4 and 5 were constructed (deduced) using the curve fitting equation for each curve (Figs. 7 and 8). These formulas can be used for specimens of series $A, B$, and $C$, with respect to $\left(f_{c}\right)$ and $\left(b_{f} / d_{f}\right)$ values. Both formulas gave almost the same result (i.e. the difference between them is negligible), for example, for the strengthening material has a strength of $500 \mathrm{~kg} / \mathrm{cm}^{2}$, and $\left(b_{f} / d_{f}\right)$ is 2.0 , we can use one formula only, as following:

The section capacity gain (assuming use series A)

$=-8.81 * 2^{2}-22.6 * 2+124.91=\underline{44.47 \%}$

Or

$=-2 * 10^{-7} * 500^{2}+0.049 * 500+20.115=\underline{44.56 \%}$

Also, ultimate loads and deflections at midpoint results of the tested beam are listed in Table 6 .

\section{CONCLUSIONS}

The most important conclusions drawn from this study can be briefly presented as follows:

Tuning of the finite element model provided good agreement with experimental test results [1], in terms of mode of failure, ultimate load, and load-deflection relationship, which demonstrated the ability of the developed models to successfully predict the flexural behavior of cold-formed steel I-beam with strengthened hollow tubular flanges. Therefore, the flexural behavior of the studied section was investigated with a varying rectangularity aspect ratio of the steel flanges and compressive strength of the strengthening material.
For specimens of series $\mathrm{A}$, using the aspect ratio of the tubular flanges $\left(\mathrm{b}_{\mathrm{f}} / \mathrm{d}_{\mathrm{f}}\right)$ equal to $0.5,1,1.5$, and 2 , increased the section capacity up to $137.27 \%, 128.78 \%, 92.51 \%$, and $66.21 \%$, respectively (compared with the control specimens). Also, the increase of the section capacity compared to the specimen with an aspect ratio of flanges equal to 1 was calculated which equal to $13.23 \%$ when using specimens with an aspect ratio of the tubular flanges equal to 0.5 , but using specimens with an aspect ratio of the tubular flanges equal to 1.5 and 2 decreased the section capacity compared to the specimen with an aspect ratio of flanges equal to 1 up to $20.12 \%$ and $32.55 \%$, respectively.

$>$ For series $\mathrm{B}$, the section capacity was increased up to $153.62 \%, 139.62 \%, 105.39 \%$, and $76.20 \%$, with the aspect ratio of the tubular flanges $\left(\mathrm{b}_{\mathrm{f}} / \mathrm{d}_{\mathrm{f}}\right)$ equal to $0.5,1$, 1.5 , and 2, respectively (compared with the control specimens). Also, the section capacity increased up to $7.56 \%, 5.27 \%, 6.69 \%$, and $6.01 \%$, respectively compared with the duplicated specimens in series A.

Also, the increase of the section capacity compared to the specimen with an aspect ratio of flanges equal to 1 was calculated which equal to $14.14 \%$ when using specimens with an aspect ratio of the tubular flanges equal to 0.5. But, using specimens with an aspect ratio of the tubular flanges equal to 1.5 and 2 decreased the section capacity compared to the specimen with an aspect ratio of flanges equal to 1 up to $20.19 \%$ and $32.04 \%$, respectively.

$>$ For series $\mathrm{C}$, the section capacity was increased by up to $141.82 \%, 132.65 \%, 94.84 \%$, and $67.72 \%$, when using the aspect ratio of the tubular flanges $\left(\mathrm{b}_{\mathrm{f}} / \mathrm{d}_{\mathrm{f}}\right)$ equal to 0.5 , $1,1.5$, and 2 , respectively (compared with the control specimens). Also, the section capacity was increased by up to $3.43 \%, 3.20 \%, 2.68 \%$, and $2.37 \%$, respectively compared with the duplicated specimens in series A, which indicated that stiffening the tension flange did not show an obvious effect on the section capacity of the strengthened specimens. Finally, for strengthened hollow tubular flange beam, checking the normal stress at the tension flange must be performed.

TABLE 4

NEW FORMULAE FOR PREDICTING THE FLEXURAL CAPACITY GAIN OF SERIES A, B, AND C SPECIMENS (WITH THE VALUE OF $\mathrm{f}_{\mathrm{c}}$ AS A FUNCTION OF $\mathrm{b}_{\mathrm{f}} / \mathrm{d}_{\mathrm{f}}$ ) AS A PERCENTAGE OF CONTROL SPECIMEN CAPACITY.

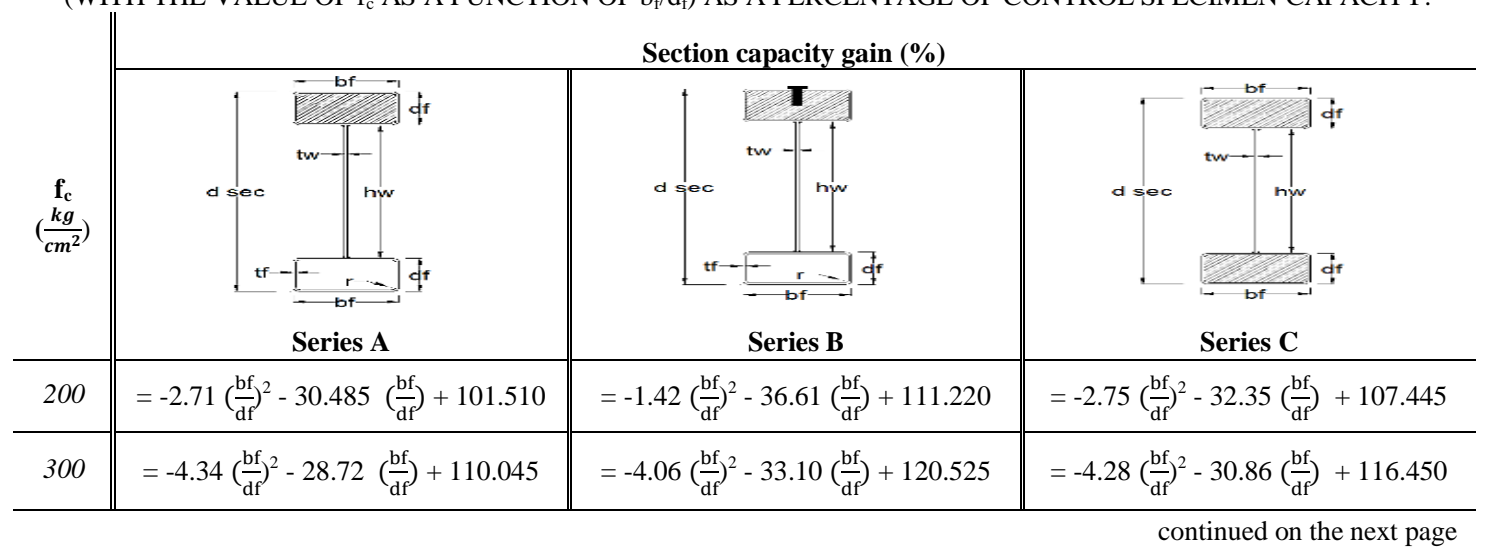


C: 18 MANSOURA ENGINEERING JOURNAL, (MEJ), VOL. 46, ISSUE 3, SEPTEMBER 2021

TABLE 4: continued

\begin{tabular}{c||c||c||c}
\hline \multicolumn{1}{c||c|}{$\begin{array}{c}\mathbf{f}_{\mathrm{c}} \\
\left(\frac{\mathrm{kg}}{\mathrm{cm}}\right)\end{array}$} & Series A & Section capacity gain $(\%)$ & Series C \\
\hline 400 & $=-6.43\left(\frac{\mathrm{bf}}{\mathrm{df}}\right)^{2}-26.03\left(\frac{\mathrm{bf}}{\mathrm{df}}\right)+117.817$ & $=-5.95\left(\frac{\mathrm{bf}}{\mathrm{df}}\right)^{2}-31.73\left(\frac{\mathrm{bf}}{\mathrm{df}}\right)+130.850$ & $=-6.51\left(\frac{\mathrm{bf}}{\mathrm{df}}\right)^{2}-28.35\left(\frac{\mathrm{bf}}{\mathrm{df}}\right)+125.334$ \\
\hline 500 & $=-8.81\left(\frac{\mathrm{bf}}{\mathrm{df}}\right)^{2}-22.60\left(\frac{\mathrm{bf}}{\mathrm{df}}\right)+124.910$ & $=-8.27\left(\frac{\mathrm{bf}}{\mathrm{df}}\right)^{2}-29.06\left(\frac{\mathrm{bf}}{\mathrm{df}}\right)+139.970$ & $=-8.96\left(\frac{\mathrm{bf}}{\mathrm{df}}\right)^{2}-24.67\left(\frac{\mathrm{bf}}{\mathrm{df}}\right)+132.575$ \\
\hline 600 & $=-11.56\left(\frac{\mathrm{bf}}{\mathrm{df}}\right)^{2}-17.51\left(\frac{\mathrm{bf}}{\mathrm{df}}\right)+130.830$ & $=-9.45\left(\frac{\mathrm{bf}}{\mathrm{df}}\right)^{2}-27.86\left(\frac{\mathrm{bf}}{\mathrm{df}}\right)+148.920$ & $=-11.51\left(\frac{\mathrm{bf}}{\mathrm{df}}\right)^{2}-19.61\left(\frac{\mathrm{bf}}{\mathrm{df}}\right)+137.667$ \\
\hline 700 & $=-14.55\left(\frac{\mathrm{bf}}{\mathrm{dff}}\right)^{2}-11.77\left(\frac{\mathrm{bf}}{\mathrm{df}}\right)+136.156$ & $=-11.27\left(\frac{\mathrm{bf}}{\mathrm{df}}\right)^{2}-25.37\left(\frac{\mathrm{bf}}{\mathrm{df}}\right)+156.945$ & $=-14.55\left(\frac{\mathrm{bf}}{\mathrm{df}}\right)^{2}-13.78\left(\frac{\mathrm{bf}}{\mathrm{df}}\right)+143.000$ \\
\hline 800 & $=-17.80\left(\frac{\mathrm{bf}}{\mathrm{df}}\right)^{2}-5.37\left(\frac{\mathrm{bf}}{\mathrm{df}}\right)+141.080$ & $=-15.20\left(\frac{\mathrm{bf}}{\mathrm{df}}\right)^{2}-15.32\left(\frac{\mathrm{bf}}{\mathrm{df}}\right)+159.711$ & $=-17.95\left(\frac{\mathrm{bf}}{\mathrm{df}}\right)^{2}-7.25\left(\frac{\mathrm{bf}}{\mathrm{df}}\right)+147.850$ \\
\hline
\end{tabular}

Where:- $f_{c}$ is the compressive strength of the used strengthening material, and $\left(\frac{b f}{d f}\right)$ is the rectangularity aspect ratio of the steel flanges.

TABLE 5

NEW FORMULAE FOR PREDICTING THE FLEXURAL CAPACITY GAIN OF SERIES A, B, AND C SPECIMENS (WITH THE VALUE OF $b_{f} / d_{f}$ AS A FUNCTION OF $f_{c}$ ) AS A PERCENTAGE OF CONTROL SPECIMEN CAPACITY.

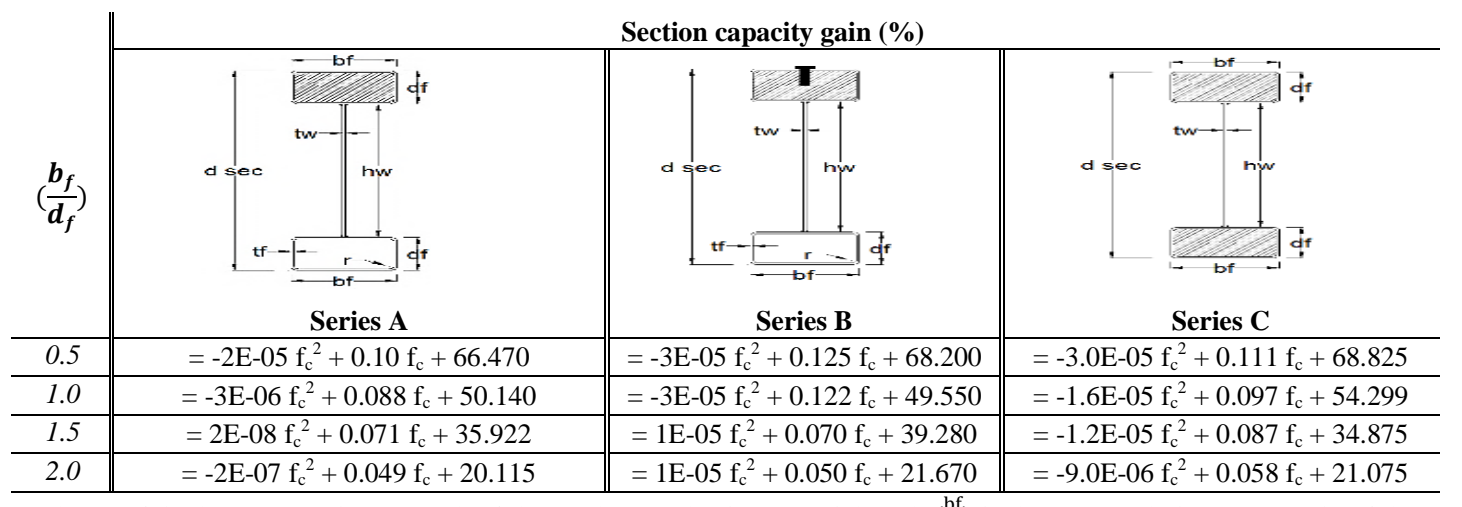

Where: $-f_{c}$ is the compressive strength of the used strengthening material, and $\left(\frac{b f}{d f}\right)$ is the rectangularity aspect ratio of the steel flanges.

TABLE 6

FE RESULTS OF THE PARAMETRIC STUDY MODELS.

\begin{tabular}{|c|c|c|c|c|c|c|}
\hline Model No. & \multicolumn{3}{|c|}{ Parameter study } & $\begin{array}{l}\text { Ultimate } \\
\operatorname{load}(k N)\end{array}$ & $\begin{array}{c}\begin{array}{c}\text { FE-model } \\
\text { mid-span deflection } \\
(\mathbf{m m})\end{array} \\
\end{array}$ & $\begin{array}{c}\text { Ultimate load } \\
\text { increase w.r.t } \\
\text { control model }(\%)\end{array}$ \\
\hline 1 & 0.5 & - & - & 174.46 & 16.78 & - \\
\hline 3 & 1.5 & - & - & 157.83 & 18.18 & - \\
\hline 4 & 2 & - & - & 154.37 & 20.33 & - \\
\hline 5 & 0.5 & 200 & $\mathrm{~A}$ & 325.00 & 43.24 & 86.29 \\
\hline 8 & 0.5 & 500 & $\mathrm{~A}$ & 372.70 & 42.01 & 113.63 \\
\hline 9 & 0.5 & 600 & A & 386.58 & 41.48 & 121.59 \\
\hline 10 & 0.5 & 700 & $\mathrm{~A}$ & 400.33 & 41.17 & 129.47 \\
\hline 11 & 0.5 & 800 & $\mathrm{~A}$ & 413.94 & 40.54 & 137.27 \\
\hline 12 & 1 & 200 & $\mathrm{~A}$ & 287.04 & 45.93 & 72.64 \\
\hline 13 & 1 & 300 & $\mathrm{~A}$ & 302.57 & 45.54 & 81.98 \\
\hline 19 & 1.5 & 200 & $\mathrm{~A}$ & 234.87 & 46.72 & 48.81 \\
\hline 20 & 1.5 & 300 & $\mathrm{~A}$ & 246.27 & 46.32 & 56.03 \\
\hline 21 & 1.5 & 400 & $\mathrm{~A}$ & 257.78 & 45.82 & 63.33 \\
\hline 22 & 1.5 & 500 & $\mathrm{~A}$ & 269.41 & 45.39 & 70.69 \\
\hline 23 & 1.5 & 600 & $\mathrm{~A}$ & 280.79 & 44.81 & 77.91 \\
\hline
\end{tabular}


TABLE 6: CONTINUED

\begin{tabular}{|c|c|c|c|c|c|c|}
\hline \multirow[b]{2}{*}{ Model No. } & \multicolumn{3}{|c|}{ Parameter study } & \multirow[b]{2}{*}{$\begin{array}{l}\text { Ultimate } \\
\text { load }(\mathbf{k N})\end{array}$} & \multirow{2}{*}{$\begin{array}{c}\text { FE-model } \\
\text { mid-span deflection } \\
(\mathrm{mm})\end{array}$} & \multirow[b]{2}{*}{$\begin{array}{c}\text { Ultimate load } \\
\text { increase w.r.t } \\
\text { control model }(\%)\end{array}$} \\
\hline & A.R. of flanges $\left(b_{f} / d_{f}\right)$ & $\begin{array}{c}\text { Compressive strength } \\
\text { of Strengthening } \\
\text { materials }\left(\mathbf{f}_{\mathrm{c}}\right)\left(\mathrm{kg} / \mathrm{cm}^{2}\right)\end{array}$ & Model series & & & \\
\hline 24 & 1.5 & 700 & $\mathrm{~A}$ & 292.27 & 44.49 & 85.18 \\
\hline 25 & 1.5 & 800 & $\mathrm{~A}$ & 303.84 & 43.80 & 92.51 \\
\hline 26 & 2 & 200 & $\mathrm{~A}$ & 204.61 & 52.73 & 32.55 \\
\hline 27 & 2 & 300 & $\mathrm{~A}$ & 213.28 & 52.28 & 38.16 \\
\hline 28 & 2 & 400 & $\mathrm{~A}$ & 221.95 & 51.71 & 43.78 \\
\hline 29 & 2 & 500 & $\mathrm{~A}$ & 230.63 & 51.23 & 49.40 \\
\hline 30 & 2 & 600 & $\mathrm{~A}$ & 239.28 & 50.58 & 55.00 \\
\hline 31 & 2 & 700 & $\mathrm{~A}$ & 247.93 & 50.21 & 60.61 \\
\hline 32 & 2 & 800 & $\mathrm{~A}$ & 256.58 & 49.44 & 66.21 \\
\hline 33 & 0.5 & 200 & $\mathrm{~B}$ & 337.49 & 45.61 & 93.45 \\
\hline 34 & 0.5 & 300 & $\mathrm{~B}$ & 354.72 & 45.36 & 103.33 \\
\hline 35 & 0.5 & 400 & $\mathrm{~B}$ & 375.22 & 44.94 & 115.07 \\
\hline 36 & 0.5 & 500 & $\mathrm{~B}$ & 394.92 & 43.87 & 126.37 \\
\hline 37 & 0.5 & 600 & $\mathrm{~B}$ & 411.43 & 43.64 & 135.83 \\
\hline 38 & 0.5 & 700 & $\mathrm{~B}$ & 430.60 & 41.82 & 146.82 \\
\hline 39 & 0.5 & 800 & $\mathrm{~B}$ & 442.47 & 41.17 & 153.62 \\
\hline 40 & 1 & 200 & $\mathrm{~B}$ & 295.67 & 48.45 & 77.83 \\
\hline 41 & 1 & 300 & $\mathrm{~B}$ & 313.63 & 48.18 & 88.63 \\
\hline 42 & 1 & 400 & $\mathrm{~B}$ & 332.94 & 47.73 & 100.25 \\
\hline 43 & 1 & 500 & $\mathrm{~B}$ & 351.81 & 46.60 & 111.59 \\
\hline 44 & 1 & 600 & B & 366.45 & 46.35 & 120.40 \\
\hline 45 & 1 & 700 & B & 384.13 & 44.42 & 131.03 \\
\hline 46 & 1 & 800 & $\mathrm{~B}$ & 398.41 & 43.73 & 139.62 \\
\hline 47 & 1.5 & 200 & B & 240.04 & 49.28 & 52.09 \\
\hline 48 & 1.5 & 300 & B & 251.97 & 49.01 & 59.65 \\
\hline 49 & 1.5 & 400 & $\mathrm{~B}$ & 266.37 & 48.55 & 68.77 \\
\hline 50 & 1.5 & 500 & $\mathrm{~B}$ & 280.76 & 47.40 & $\begin{array}{l}77.89 \\
\end{array}$ \\
\hline 51 & 1.5 & 600 & $\mathrm{~B}$ & 293.96 & 47.15 & 86.25 \\
\hline 52 & 1.5 & 700 & $\mathrm{~B}$ & 309.71 & 45.19 & 96.23 \\
\hline 53 & 1.5 & 800 & B & 324.17 & 44.49 & 105.39 \\
\hline 54 & 2 & 200 & B & 208.46 & 55.62 & 35.04 \\
\hline 55 & 2 & 300 & $\mathrm{~B}$ & 217.48 & 55.32 & 40.89 \\
\hline 56 & 2 & 400 & $\mathrm{~B}$ & 228.50 & 54.80 & 48.02 \\
\hline 57 & 2 & 500 & $\mathrm{~B}$ & 239.09 & 53.50 & 54.88 \\
\hline 58 & 2 & 600 & $\mathrm{~B}$ & 249.09 & 53.22 & 61.36 \\
\hline 59 & 2 & 700 & B & 261.14 & 51.00 & 69.17 \\
\hline 60 & 2 & 800 & B & 272.00 & 50.21 & 76.20 \\
\hline 61 & 0.5 & 200 & $\mathrm{C}$ & 333.96 & 44.64 & 91.43 \\
\hline 62 & 0.5 & 300 & $\mathrm{C}$ & 349.54 & 44.59 & 100.36 \\
\hline 63 & 0.5 & 400 & $\mathrm{C}$ & 369.16 & 44.28 & 111.60 \\
\hline 64 & 0.5 & 500 & $\mathrm{C}$ & 383.78 & 44.14 & 119.98 \\
\hline 65 & 0.5 & 600 & $\mathrm{C}$ & 394.01 & 43.09 & 125.85 \\
\hline 66 & 0.5 & 700 & $\mathrm{C}$ & 409.89 & 43.07 & 134.95 \\
\hline 67 & 0.5 & 800 & $\mathrm{C}$ & 421.87 & 40.84 & 141.82 \\
\hline 68 & 1 & 200 & $\mathrm{C}$ & 294.23 & 47.42 & 76.96 \\
\hline 69 & 1 & 300 & $\mathrm{C}$ & 309.36 & 47.36 & 86.06 \\
\hline 70 & 1 & 400 & $\mathrm{C}$ & 328.55 & 47.03 & 97.60 \\
\hline 71 & 1 & 500 & $\mathrm{C}$ & 343.67 & 46.89 & 106.70 \\
\hline 72 & 1 & 600 & $\mathrm{C}$ & 355.39 & 45.77 & 113.74 \\
\hline 73 & 1 & 700 & $\mathrm{C}$ & 372.71 & 45.74 & 124.16 \\
\hline 74 & 1 & 800 & $\mathrm{C}$ & 386.83 & 43.38 & 132.65 \\
\hline 75 & 1.5 & 200 & $\mathrm{C}$ & 239.60 & 48.23 & 51.81 \\
\hline 76 & 1.5 & 300 & $\mathrm{C}$ & 250.56 & 48.18 & 58.75 \\
\hline 77 & 1.5 & 400 & $\mathrm{C}$ & 264.68 & 47.84 & 67.70 \\
\hline 78 & 1.5 & 500 & $\mathrm{C}$ & 275.40 & 47.69 & 74.49 \\
\hline 79 & 1.5 & 600 & $\mathrm{C}$ & 284.14 & 46.56 & 80.03 \\
\hline 80 & 1.5 & 700 & $\mathrm{C}$ & 297.14 & 46.53 & 88.27 \\
\hline 81 & 1.5 & 800 & $\mathrm{C}$ & 307.52 & 44.13 & 94.84 \\
\hline 82 & 2 & 200 & $\mathrm{C}$ & 208.16 & 54.44 & 34.85 \\
\hline 83 & 2 & 300 & $\mathrm{C}$ & 216.37 & 54.38 & 40.17 \\
\hline 84 & 2 & 400 & $\mathrm{C}$ & 227.21 & 54.00 & \begin{tabular}{|l}
47.19 \\
\end{tabular} \\
\hline 85 & 2 & 500 & $\mathrm{C}$ & 235.02 & 53.83 & 52.25 \\
\hline 86 & 2 & 600 & $\mathrm{C}$ & 241.45 & 52.55 & 56.41 \\
\hline 87 & 2 & 700 & $\mathrm{C}$ & 251.33 & 52.52 & 62.81 \\
\hline 88 & 2 & 800 & $\mathrm{C}$ & 258.91 & 49.81 & 67.72 \\
\hline
\end{tabular}




\section{Authors Contribution}

Ashraf M. Abou-Rayan:

published.

He provided the final approval of the version to be

Nader N. Khalil:

He substantially contributed the conception or design of the work, data collection and tools, data analysis and interpretation, methodology, project administration, and final approval of the version to be published.

Ayman A. Zaky:

He determined the tools of data collection, data analysis and interpretation, drafting the article, and critical revision of the article.

\section{REFERENCES}

[1] A. M. Abou-Rayan, N. N. Khalil, A. A. Zaky, Experimental investigation on the flexural behavior of steel cold-formed I-beam with strengthened hollow tubular flanges, Thin-Walled Structures 155 (2020) 106971.

[2] C. Yu, B.W. Schafer, Simulation of cold-formed steel beams in local and distortional buckling with applications to the direct strength method, J. Constr. Steel Res. 63 (2007) 581-590.

[3] ABAQUS. ABAQUS Version 6.2. Pawtucket (RI): ABAQUS, Inc; 2001. http://www.abaqus.com.

[4] Y. Shifferaw, B. W. Schafer, Inelastic bending capacity of cold-formed steel members, J. Struct. Eng. 138 (2012) 468-480.

[5] W. Ma, J. J. Becque, I. Hajirasouliha, J. Ye, Cross-sectional optimization of cold-formed steel channels to Eurocode 3, Eng. Struct. 101 (2015) 641-651.

[6] CEN. Eurocode 3: Design of steel structures, Part 1.3: General rulessupplementary rules for cold-formed members and sheeting. Brussels: European Committee for Standardization; 2005.

[7] E. Magnucka-Blandzi, P. Paczos, P. Wasilewicz, Buckling study of thinwalled channel beams with double-box flanges in pure bending, Strain 48 (2012) 317-325.

[8] R. Siahaan, P. Keerthan, M. Mahendran, Finite element modeling of rivet fastened rectangular hollow flange channel beams subject to local buckling, Eng. Struct. 126 (2016) 311-327.

[9] Standards Australia. Australia/New Zealand Standard AS/NZS 4600 cold-formed steel structures. Sydney, Australia; 2005.

[10] Standards Australia. Australian Standard AS 4100 steel structures. Sydney, Australia; 1998.

[11] AISI. North American specification for the design of cold-formed steel structural members. Washington (DC, USA): American Iron and Steel Institute; 2012.

[12] R. Siahaan, P. Keerthan, M. Mahendran, Section moment capacity design rules for rivet fastened rectangular hollow flange channel beams, Thin-Walled Struct. 127 (2018) 781-797.

[13] J. Dong, R. Sause, Flexural strength of tubular flange girders, J. Constr. Steel Res. 65 (2009) 622-630.

[14] M. Karunakaran, M.H. Santhi, Investigation on cold-formed steel rectangular hollow flanged 'Z' beam section, Int. J. Recent Res. Sci. Eng. Technol. 2(10), (2014) 1-7.

[15] ANSYS program revision 14. ANSYS Inc., Canonsburg, PA.
[16] N. Tondini, A. Morbioli, Cross-sectional flexural capacity of coldformed laterally-restrained steel rectangular hollow flange beams, ThinWalled Struct. 95 (2015) 196-207.

[17] B. G. Kim, R. Sause, Lateral torsional buckling strength of tubular flange girders. Journal of Structural Engineering ASCE 2008; 134(6):902-910.

[18] T. Anapayan, M. Mahendran, Improved design rules for hollow flange sections subject to lateral distortional buckling, Thin-Walled Struct. 50 (2012) 128-140.

[19] M.F. Hassanein, O.F. Kharoob, A.M. El Hadidy, Lateral-torsional buckling of hollow tubular flange plate girders with slender stiffened webs, Thin-Walled Struct. 65 (2013) 49-61.

[20] M.F. Hassanein, N. Silvestre, Lateral-distortional buckling of hollow tubular flange plate girders with slender unstiffened webs, Eng. Struct. 56 (2013) 572-584.

[21] N.S. Trahair, J.P. Papangelis, Lateral-distortional buckling of beams with hollow flanges and folded plate webs, Eng. Struct. 163 (2018) 7176.

[22] P. Kyvelou. Structural behavior of composite cold-formed steel systems. $\mathrm{Ph} . \mathrm{D}$. thesis. Imperial College London, Department of civil and environmental engineering, February 2017.

[23] K. He, Y. Chen, J. Wan, Web crippling behavior of grouted galvanized rectangular steel tube, Thin-Walled Struct. 122 (2018) 300-313.

[24] Uang C, Bruneau M, Whittaker A. Ductile design of steel structures, McGraw-Hill, New York; 1998.

\section{Title Arabic:}

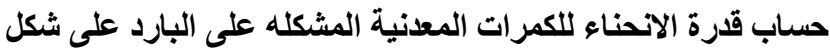

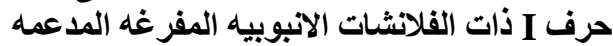

\section{Arabic Abstract:}

يقدم هذا البحث صيغ جديده لدر اسة سلوك الانحناء للكمرات المعدنية المشكله

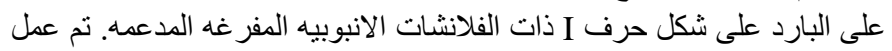

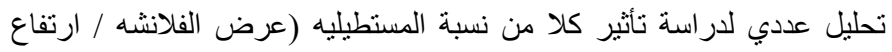

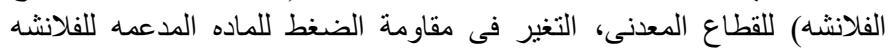

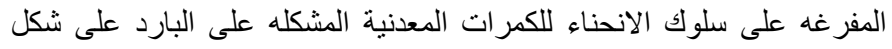

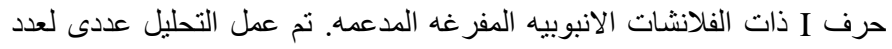

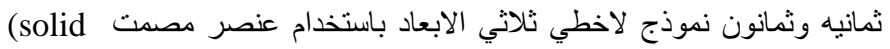
element with 3DOF) المحددة (ANSYS-version 14). تم تجهيز واختبار عدد تسعة عشره عينة

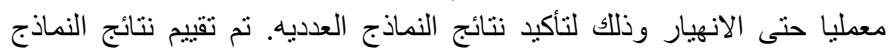

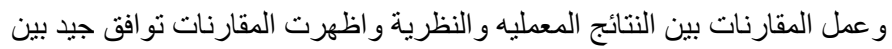

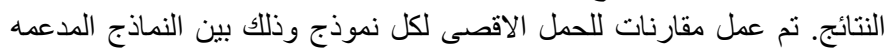

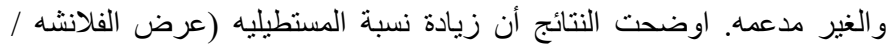

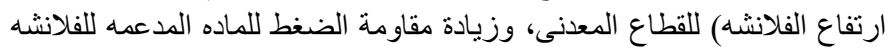

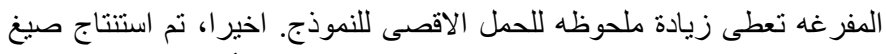
لحساب قيم الحمل الاقصى للقطاع المدعم وذللك تحت تأثير المتغيرات التهل محل الدراسه. 